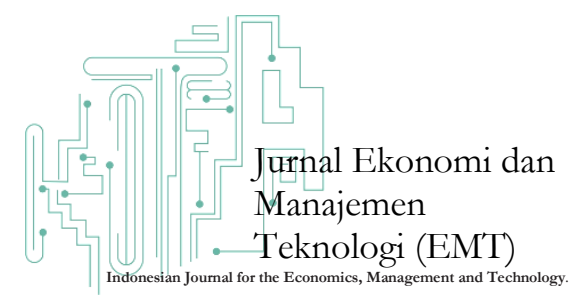

Jurnal Ekonomi dan Manajemen Teknologi, 3(2), 2019, 61-69

Available online at http://journal.lembagakita.org

\title{
Transparansi Pengelolaan Dana Desa di Kabupaten Bireun
}

\author{
Ayumiati $^{1}$, Isnaliana ${ }^{2}$, Jalilah $^{3}$ \\ 1,2,3 Fakultas Ekonomi dan Bisnis Islam, Universitas Islam \\ Negeri Ar-raniry, Banda Aceh
}

\begin{abstract}
Abstrak. Dana desa merupakan dana yang bersumber dari Anggaran Pendapatan dan Belanja Negara yang diperuntukkean bagi desa yang ditransfer melalui Anggaran Pendapatan dan Belanja Daerah Kabupaten/Kota dan digunakan untuk. mendanai penyelenggaraan pemerintaban, pelaksanaan pembangunan, pembinaan kemasyarakatan, dan pemberdayaan masyarakat, serta transparansi. Tujuan studi ini untuk mengetabui transparansi pengelolaan dana desa di Kabupaten Bireun. Adapun jenis penelitian ini adalab desktiptif analisis dengan pendekatan kualitatif. Hasil penelitian menunjukkan pengelolaan dana gampong di kabupaten Bireun sudah transparan dibuktikan dengan keterbukaan dalam proses perencanaan, penyusunan dan pelaksanaan Anggaran Dana Desa.
\end{abstract}

Kata kunci: Anggaran, Dana Desa, Transparansi.

Abstract. Village funds represent funds sourced from the State Revenue and Expenditure Budget which is intended for villages that are transferred through the Regency / City Regional Revenue and Expenditure Budget and are used to fund governance, development implementation, community development, and community empowerment, and transparency. The purpose of this study is to find out the transparency of village fund management in Bireun District. This type of research is descriptive analysis with a qualitative approach. The results showed that the management of village funds in Bireun district was transparent as evidenced by the openness in the process of planning, drafting and implementing the Village Fund Budget.

Keywords: Budget, Village Funds, Transparency

*Corresponding author. Email: cut_ayumiati@gmail.com¹, Isna_liana90@yahoo.com², jalilahusfar@gmail.com ${ }^{3}$

DOI: https://doi.org/10.35870/emt.v3i2.99

Received: 29 June 2019, Revision: 10 October 2019, Accepted: 20 November 2019

Print ISSN: 2579-7972; Online ISSN: 2549-6204.

Copyright@2019. Published by Divisi Riset, Lembaga KITA. 


\section{Pendahuluan}

Indonesia merupakan negara yang mengalami beberapa perubahan dalam sistem pemerintahan sesuai dengan situasi dan kondisi perkembangan masyarakat dan pengelolaan system pemerintahan. Ada beberapa perubahan sistem pemerintahan di Indonesia berdasarkan tiga konstitusi yang pernah berlaku yaitu Undang-Undang Dasar 1945, Konstitusi RIS, dan UUDS 1950. Selain itu Indonesia adalah salah satu negara republik yang pemerintahannya terdiri dari pemerintah pusat dan pemerintah daerah. Untuk daerah terbagi atas provinsi, kabupaten/kota dan kecamatan. Pada kecamatan juga terdapat pemerintahan kecil yang di sebut dengan desa (gampong). Pada praktinya sistem penyebutan terhadap desa di Indonesia tidak semuanya seragam, seperti Aceh yang menyebutnya gampong dan Sumatera Barat dengan sebutan Nigari dan masih banyak sebutan lain untuk istilah desa sesuai dengan daerah tersebut.

Menurut UU Nomor 6 tahun 2014 pasal 1, sistem pemerintahan paling dasar di Indonesia adalah pemerintahan gampong serta merupakan pemerintahan yang paling dekat dan berhubungan langsung dengan masyarakat. Tetapi selama ini pemerintahan gampong kurang mendapat perhatian dari pemerintah, hal ini dapat menyebabkan banyaknya gampong yang tertinggal di seluruh pelosok Indonesia. Untuk meminimalisir hal tersebut maka dikeluarkan peraturan pemerintah republik Indonesia nomor 60 tahun 2014 tentang dana gampong yang bersumber dari Anggaran Pendapatan dan Belanja Negara.

Dalam penyelenggarannya, sistem pemerintah gampong memiliki kewenangan untuk mengatur, menjalakan dan melaksanakan kepentingan masyarakat. Gampong juga mempunyai peranan penting dalam otonomi gampong dan berpijak pada prinsip good governance dengan prinsip efisien, efektif, transparansi, akuntabilitas serta demokrasi dalam pelaksanaan pemerintah. Sebagaimana Djiwadono, 1981 (yang dikutip oleh Nurman 2015:241) menyatakan bahwa tujuan pembagunan gampong meliputi: Pertama, tujuan ekonomi untuk meningkatkan produktivitas di daerah pergampongan dalam rangka mengurangi kemiskinan dipergampongan. Kedua, tujuan sosial diarahkan pada pemerataan kesejahteraan penduduk gampong. Ketiga, kutural dalam meningkatkan kualitas hidup pada umumnya di masyarakat gampong. Keempat, tujuan kebijakan menumbuhkan dan mengembangkan partisipasi masyarakat gampong secara maksimal dalam meningkatkan pembangunan dan mengembangkan pembagunan.

Undang-Undang Nomor 32 Tahun 2004 tentang Pemerintah Daerah pada prinsipnya, mengatur penyelenggaraan pemerintah daerah yang lebih mengutamakan pelaksanaan asas desentralisasi. Dampak lain yang muncul dengan adanya otonomi daerah adalah tuntutan terhadap pemerintah dalam menciptakan good governance sebagai prasyarat dengan mengedepankan akuntanbilitas, transparansi dan partisipasi. Sehubungan dengan hal itu maka peran kepala gampong menjadi penting dalam mengontrol kebijakan pemerintahan gampong (Sutrisno, 2017).

Transparansi merupakan hal yang sangat penting dalam pengelolaan anggaran bagi setiap organisasi pemerintahan. Transparansi merupakan organisasi yang menyediakan informasi secara terbuka yang menyangkut informasi yang relevan serta mudah di akses dan di fahami oleh pemangku kepentingan (Atmadja, dkk 2013:19).

Pentingnya transparansi dalam pengolalaan dana gampong supaya tidak terjadinya penyalahgunaan anggaran gampong oleh pemerintahan gampong. Maraknya terjadi penyalahgunaan anggaran dana gampong disebabkan oleh kurangnya pengetahuan dan pemahaman perangkat gampong dalam pengelolaan anggaran dana gampong seperti kasus yang terjadi di daerah Gampong Keude Aceh Timur, dimana modus yang terjadi dalam pengelolaan dana gampong antara lain dalam bentuk honor pekerja yang tidak sesuai dengan Rencana Anggaran Biaya (RAB), pelaksanaan atau pengadaan barang fiktif, penggelembungan harga barang dan pemotongan oleh oknum perangkat gampong atau kecamatan (Tribunnews.com). Sehingga kajian ini menarik untuk dikaji lebih mendalam oleh peneliti di provinsi Aceh khususunya di kabupaten Bireun. 
Aceh sebagai salah satu provinsi dan daerah yang memiliki otonomi khusus, ditambah lagi dengan adanya kebijakan dana desa (ADD) menyebabkan Aceh akan berkembang dan bangkit dari keterpurukan khususnya gampong, yang selama ini jauh dari perhatian pemerintah pusat. Dengan hadirnya ADD, dan pengelolaannya yang akuntabilitas, transparansi dan partisipasi merupakan harapan pemerintah pada setiap gampong sehingga nantinya dapat meningkatkan produktivitas pembangunan baik dari segi infrastruktur maupun kesejahteraan (pemberdayaan).

Dana desa merupakan dana yang bersumber dari Anggaran Pendapatan dan Belanja Negara yang diperuntukkan bagi desa yang ditransfer melalui Anggaran Pendapatan dan Belanja Daerah kabupaten/kota dan digunakan untuk mendanai penyelenggaraan pemerintahan, pelaksanaan pembangunan, pembinaan kemasyarakatan, dan pemberdayaan masyarakat. Adapun anggaran ini dikelola oleh pemerintah desa yaitu kepala desa atau yang disebut dengan nama lain dibantu perangkat desa sebagai unsur penyelenggaraan Pemerintahan Desa.

Adapun prioritas penggunaan Dana Desa harus di dasarkan pada prinsip keadilan, dimana mengutamakan hak dan kepentingan seluruh warga Desa tanpa membeda-bedakannya. Kemudian memprioritaskan kebutuhan dengan mendahulukan kepentingan Desa yang lebih mendesak dan berhubungan langsung dengan kepentingan sebagian besar masyarakat serta mengutamakan prakarsa dan kreatifitas masyarakat. Namun, prioritas-prioritas tersebut hanya peraturan belaka bagi pemerintahan desa dalam mengalokasikan Dana Desa. Sehingga berakibat pada penyelewengan pengelolan Dana Desa seperti kasus yang telah di sebutkan di atas.

\section{Literature Review}

anggaran sebagai salah satu komponen penting agar tetap survive dalam lingkungan yang cepat berubah serta menerjemahkan seluruh strategi menjadi rencana dan tujuan jangka pendek dan jangka panjang (Wirjono dan Raharjono, 2017). Sementara Zaenudin (2016) memberikan definisi mengenai anggaran, bahwa anggaran adalah suatu pendekatan formal dan sistematis daripada pelaksanaan tanggung jawab manajemen di dalam perencanaan, koordinasi dan pengawasan. Sedangkan penganggaran atau proses penyusunan anggaran adalah proses dimana para tingkat atas dan bawah terlibat dalam mempersiapkan dan menentukan tujuan anggaran, yang kemudian dievaluasi dan mendapat imbalan berdasarkan pencapaian anggaran sehingga pada akhirnya akan menghasilkan goal congruence yang lebih besar (Kusuma, 2016), Dengan adanya proses penganggaran diharapkan penyusunan anggaran dapat berjalan dengan baik dan lebih berkualitas serta tersistem (Alfi, 2016). jadi penganggaran adalah proses atau metode untuk mempersiapkan suatu anggaran.

Menurut Anthony dan Govindarajan (2003), proses penyusunan anggaran pada dasarnya memiliki 4 tujuan utama yaitu: (1) menyelaraskan dengan rencana strategik, (2) untuk mengkoordinasikan kegiatan dari beberapa bagian dalam organisasi, (3) untuk memberikan tanggungjawab kepada manajer atau pimpinan, guna mengotorisasi jumlah dana yang dapat digunakan, dan untuk memberitahukan hasil yang mereka capai, serta (4) untuk mencapai kerjasama (Mariastuti, 2019; Kaharti, 2019; Gusmaulita, 2018).

Penganggaran dalam organisasi sektor publik merupakan tahapan yang cukup rumit (Laksono, 2017) dan mengandung aspek yang bersifat politis sehingga proses penganggaran dalam organisasi sektor publik dapat dikategorikan sebagai proses politik bukan hanya proses ekonomi (Alfi, 2016). Hal ini sangat berbeda dengan penganggaran pada perusahaan swasta yang relatif kecil bahkan mungkin tidak mengandung aspek politis (Orinaldi dkk, 2017). Pada sektor swasta, anggaran merupakan bagian dari rahasia perusahaan yang tertutup untuk publik, namun sebaliknya pada sektor publik anggaran justru harus diinformasikan kepada publik untuk dikritik, didiskusikan, dan diberi masukan (Diana, 2016). Anggaran sektor publik merupakan instrumen akuntabilitas atas pengelolaan dana publik dan pelaksanaan program-program yang dibiayai dengan uang publik (Mardiasmo, 2002). 
Secara singkat dapat dinyatakan bahwa anggaran publik merupakan suatu rencana finansial yang menyatakan: (1) Berapa biaya atas rencana-rencana yang dibuat (pengeluaran/belanja); dan (2) Berapa banyak dan bagaimana caranya memperoleh uang untuk mendanai rencana tersebut (pendapatan) (Hidayat, 2016). Tidak semua aspek kehidupan masyarakat tercakup oleh anggaran sektor publik (Sidauruk, 2017). Terdapat beberapa aspek kehidupan yang tidak tersentuh oleh anggaran sektor publik (Satriawan, 2016), baik skala nasional maupun lokal (Muhammad, (2016). Anggaran sektor publik dibuat untuk membantu menentukan tingkat kebutuhan masyarakat, seperti listrik, air bersih, kualitas kesehatan, pendidikan dan sebagainya agar terjamin secara layak (Tahir, 2018). Tingkat kesejahteraan masyarakat dipengaruhi oleh keputusan yang diambil oleh pemerintah melalui anggaran yang mereka buat (Perdana dkk, 2017).

Transparansi artinya dalam menjalankan pemerintah, mengungkapkan hal-hal yang sifatnya material secara berkala kepada pihakpihak yang memiliki kepentingan untuk itu, dalam hal ini yaitu masyarakat luas (Pakaya dkk, 2019). Transparansi adalah prinsip memberikan informasi keuangan yang terbuka dan jujur yang memungkinkan masyarakat untuk mengetahui dan mendapatkan akses informasi seluasluasnya tentang keuangan daerah (Prayogi, 2019). Adanya transparansi menjamin akses atau kebebasan bagi setiap orang untuk memperoleh informasi tentang penyelenggaraan pemerintahan (Salle, 2016), yakni informasi tentang kebijakan (Vabiani, 2018), proses pembuatan dan pelaksanannya (Hiban, 2018), serta hasil-hasil yang dicapai. Transparansi yakni adanya kebijakan terbuka bagi pengawasan (Zulfikar, 2017).

Sedangkan yang dimaksud dengan informasi adalah informasi mengenai setiap aspek kebijakan pemerintah yang dapat dijangkau oleh publik (Devi, 2018). Transparansi atau keterbukaan di sini memberikan arti bahwa anggota masyarakat memiliki hak dan akses yang sama untuk mengetahui proses anggaran (Nurfitriani, 2018) karena menyangkut aspirasi dan kepentingan masyarakat, terutama pemenuhan kebutuhan-kebutuhan hidup masyarakat banyak (Tundunaung, Lumolos, dan Mantiri, 2018).

Transparansi dapat diartikan sebagai keterbukaan dalam proses perencanaan, penyusunan dan pelaksanaan anggaran (Yuwono, 2005). Namun Mardiasmo mengatakan bahwa transparansi adalah keterbukaan dalam proses perencanaan, penyusunan, pelaksanaan anggaran daerah (Mardiasmo, 2002). Selanjutnya Endah Jubaidah, transparansi atau keterbukaan adalah prinsip untuk membuka diri terhadap hak masyarakat untuk memperoleh akses informasi yang benar, jujur dan tidak diskriminatif tentang hak asasi pribadi, golongan, dan rahasia Negara (Jubaedah dkk, 2008).

Dalam penyajian laporan keuangan, transparansi akan menciptakan pertanggungjawaban secara horizontal (horizontal accountability) antara pemerintah gampong dengan masyarakat sehingga tercipta lembaga yang bersih, efektif, efisien, akuntabel dan responsif terhadap aspirasi dan kepentingan bersama (Bastian, 2006). Selain itu transparansi merupakan nilai yang dapat mengubah hubungan antara warga negara dan pemerintah, antara profesional dan pelanggan mereka dan antara perusahaan dengan pelanggan, investor, dan masyarakatnya (Holzner, 2006).

Untuk menindaklanjuti terselenggaranya proses pembangunan yang sejalan dengan prinsip tata pemerintahan yang baik (good governance) (Hari, 2016), pemerintah dalam hal perangkat gampong berkewajiban untuk mengembangkan dan memanfaatkan kemajuan teknologi informasi untuk meningkatkan kemampuan pengelolaan dana gampong (Asyikin dkk, 2016), dan menyalurkan Informasi Keuangan gampong kepada masyarakat (Akhmad dkk, 2017). Untuk melahirkan produk kebijakan yang berkualitas, maka dalam proses penyusunannya harus memenuhi persyaratan adanya: akuntabilitas, partisipasi dan transparansi. Dalam kaitan inilah maka partisipasi stakeholders, baik dalam tahap formulasi maupun implementasi, memainkan peranan yang sangat penting. Peran serta stakeholder dapat menjadi salah satu indikator transparansi (Rahman dan Sucipto, 2018). 


\section{Metodologi Penelitian}

Penelitian ini menggunakan metode desktiptif analisis dengan pendekatan kualitatif. Penggunaan metode ini disesuaikan dengan tujuan pokok penelitian, yaitu mendeskripsikan dan menganalisis mengenai model pengelolaan anggaran dana desa di kabupaten Bireun. Peneliti juga berharap wilayah ini mendapatkan data yang valid terhadap isu yang di bahas, disamping itu wilayah tersebut dapat menjadi perbandingan dalam melakukan pengumpulan data. Adapun teknik yang digunakan peneliti dalam pengumpulan data dilakukan secara terencana, sistematis dan konsisten. Karena penelitian ini bersifat lapangan (field research) dan perpustakaan (library research), maka metode pengumpulan data yang dilakukan adalah wawancara mendalam, partisipasi observasi, FGD dan kajian dokumentasi.

\section{Hasil dan Pembahasan}

Kabupaten Bireuen adalah salah satu Daerah Tingkat II di provinsi Nanggroe Aceh Darussalam. Menjadi kabupaten otonom sejak tahun 2000 sebagai hasil pemekaran dari kabupaten Aceh Utara. Kabupaten ini terkenal dengan julukan kota Juangnya. Sejak berdirinya Kabupaten Bireuen berdasarkan Undangundang No.48 tahun 1999 telah terjadi perkembangan yang cukup signifikan dalam bidang pemerintahan, di mana pada awalnya terdiri dari 7 (tujuh) Kecamatan, namun sampai dengan akhir tahun 2006 telah dimekarkan menjadi 17 Kecamatan salah satunya adalah kecamatan kota Juang dengan lokasi Gampong Bireun Menasah Blang dan Gampong Bireun Meunasah Dayah.

Dari hasil penelusuran, kedua gampong tersebut mempunyai hasil sumber daya alam pada bidang pertanian dan perkebunan yang dapat menjadi sumber pendapatan gampong yang bisa menjadi Anggaran Pendapatan dan Belanja Gampong (APBG). Oleh karena itu, mata pencaharian sebagian besar penduduk gampong adalah bidang cocok tanam, peternakan dan tanaman perkebunan. Semua sektor tersebut mempunyai potensi besar untuk dikembangkan dan perlu pembenahan karena masyarakat butuh peningkatan kapasitas berupa penyuluhan dan pelatihan di bidang yang digeluti oleh masing-masing masyarakat gampong.

Hingga saat ini, kemampuan keuangan Gampong Bireun Meunasah Blang dan Gampong Bireun Meunasah Dayah masih mengandalkan bantuan dari pemerintah berupa Anggaran Dana Desa (ADD), sementara untuk pendapatan asli gampong dan bantuan pihak ketiga masih kurang terutama dalam dukungan tanah wakaf desa dan sewa tanah lainnya. Ke depan dengan adanya dana desa gampong ini berencana untuk memperkuat sektor-sektor yang berpotensi meningkatkan pendapatan asli gampong.

Alokasi anggaran dana desa berjalan dengan baik dan telah melalui tahap pertanggungjawaban melalui SPJ ADD, dalam hal ini pertanggungjawaban dari beberapa desa masih dalam tahap penelitian oleh pemerintah daerah Kabupaten Bireun. Keberhasilan implementasi sebuah kebijakan salah satu faktor yang menentukannya adalah sosialisasi yang merupakan proses pengkomunikasian kegiatan. Terdapat 3 (tiga) hal yang perlu diperhatikan, yaitu transmisi, clarity, consistency. Dari hasil penelitian dalam hubungan sosialisasi dan pelaksanaan ADD, terdapat beberapa faktor penentu yaitu:

1) Sosialisasi telah dilakukan oleh Tim Kabupaten sementara pengawasan didelegasikan pada pelaksana program melalui pelaksanaan pertanggungjawaban kerja.

2) Pencapaian informasi dari pembuat kebijakan kepelaksana kebijakan maupun sebaliknya berjalan lancar sehingga memudahkan sistem kontrol.

3) Terdapat konsistensi dalam pencapaian pesan/perintah kebijakan artinya tidak terdapat perintah yang bertentangan.

Alokasi dan pelaksanaan anggaran dana desa gampong Bireun Meunasah Blang dan gampong Bireun Meunasah Dayah secara umum berdasarkan wawancara dan pengamatan penelitian proses pencairan Anggaran Dana Desa (ADD), yang diberikan kepada Gampong Bireuen Meunasah Blang sebagian besar sesuai dengan kebutuhan desa dan target alokasi yang direncanakan. Walaupun secara khusus memang 
belum mengcover seluruh harapan dan kebutuhan masyarakat. Mengingat terbatasnya dana anggaran yang diberikan oleh pemerintah.

Adapun perencanaan alokasi dana desa pada Gampong Bireun Meunasah Blang dan Gampong Bireun Meunasah Dayah selama ini sudah efektif, dimana jumlah dana desa yang dialokasikan sesuai dengan kebutuhan masyarakat dan ini sesuai dengan tahapan dalam penyusunan RPJM Desa. Hal ini dapat di lihat dari beberapa proses yaitu (wawancara dengan Hasmuni, 2018): Pertama Musyawarah Dusun (MUSDUS), dalam musyawarah dusun ini difasilitasi oleh Badan Permusyawaratan Desa (BPD). Anggotanya terdiri dari perwakilan tokoh masyarakat dan tokoh perempuan dari setiap dusun. Anggota ini dipilih oleh warga dusun tidak semua desa memiliki jumlah anggota BPD yang sama, hal ini tergantung dari jumlah penduduk dan luar wilayah. Jumlah anggota BPD adalah $5-11$ orang.

Selanjutnya kedua Musyawarah Desa (MUSDES), dalam musyawarah ini difasilitasi oleh Badan Permuswaratan Desa. Musyawarah desa membahas program pembangunan yang telah dibuat oleh setiap dusun, dan melalui musyarawah desa ini, Kepala Desa, BPD, dan masyarakat desa menyepakati prioritas program pembangunan. Hasil kesepakatan dalam musyawarah desa ditindaklanjuti dengan Peraturan Desa (Perdes) tentang Rencana Pembangunan Jangka Menengah Desa (RPJMDes).

Berdasarkan rapat dan musyawarah antar dusun melalui MUSDUS yang ada di gampong tersebut, kemudian baru dirapatkan atau dimusyawarahkan dengan masyarakat melalui MUSDES. Adapun dalam musyawarah tersebut setiap dusun mengusulkan akan kebutuhan yang mereka inginkan baik berupa infratruktur atau bentuk pemberdayaan lainny. Sedangkan pada MUSDES mengambil keputusan terhadap pelaksanaan tiap-tiap program yang di usulkan. Namun seluruh program yang diusulkan tidak bisa dilaksanakan secara sekaligus, mengingat keterbatasan dana, pencairan dana, dan pelaksanaan program yang membutuhkan waktu yang lama. Oleh karena itu, pada gampong ini pelaksanaan program melihat kepada kebutuhan masyarakat yang lebih mendesak (Wawancara dengan Hasmuni dan Syarifudin, 2018).

Adapun untuk anggaran dana desa itu sendiri Tahun 2017 Gampong Bireuen Meunasah Blang memperoleh Anggaran Dana Desa (ADD) sebesar Rp929.820.000,- yang dibagi pada tiga tahap penyaluran. Tahap pertama $20 \%$ dari total anggaran, tahap kedua $40 \%$ dan tahap ketiga 40\%. Hingga akhir tahun 2017 seluruh Anggaran Dana Desa telah dialokasikan sesuai dengan rancangan alokasi anggaran yang telah disepakati dan disetujui. Mengingat bahwa Gampong Bireuen Meunasah Blang memiliki daerah yang luas dan didukung jumlah masyarakat yang banyak maka dana anggaran telah terealisasikan seluruhnya. Begitu halnya dengan Bireun Meunasah Dayah Alokasi anggaran dana desa di gampong ini yang masuk tahun 2017 yaitu sebesar Rp958.970.000,- yang terbagi dalam dana desa (DD) sebesar Rp785.274.000, alokasi dana gampong (ADG) sebesar 168.049.000 dan bagi hasil pajak \& retribusi daerah (BHPRD) sebesar Rp5.647.0009.

Penerapan transparansi pengelolaan Anggaran Dana Desa di Kabupaten Bireun pada Gampong Bireun Meunasah Blang dan Bireun Meunasah Dayah bila dilihat dari beberapa indikator berikut ini sudah berjalan dengan baik: pertama, kesediaan dan aksesibilitas dokumen. Tahapan ini sudah dilakukan dengan baik oleh kedua gampong tersebut, dimana seluruh pelaporan dicatat oleh setiap bendahara gampong dan hasilnya di publis pada papan informasi. Kemudian juga dilengkapi dengan akses web pada setiap gampong. Kedua, kejelasan dan kelengkapan informasi. Pada tahapan ini setiap pelaporan yang dilaporkan sudah jelas, begitu halnya dengan kelengkapan informasi yang mereka miliki. Ketiga, keterbukaan proses. Tahap ini sudah dilakukan oleh perangkat gampong melalui MUSDUS dan MUSDES. Keempat, kerangka regulasi yang menjamin transparansi. Indikator yang terakhir ini berpayunghukumkan pada undang-undang pengelolaan anggaran dana desa.

Ditinjau dari penerapan prinsip transparansi yang merupakan keterbukaan dalam proses perencanaan, penyusunan dan pelaksanaan 
Anggaran Dana Desa. Dalam hal ini, perancangan perencanaan alokasi kebutuhan dana Gampong Bireuen Meunasah Blang dan Bireun Meunasah Dayah melibatkan seluruh perangkat gampong dan perwakilan dari masyarakat, yaitu geuchik, sekdes, bendahara, tuha peut, pemuda desa dan perwakilan masingmasing dusun. Tujuannya agar semua kebutuhan pengembangan desa dapat tercover dengan efektif dan efisien.

Keterbukaan pengalokasian ADD juga dapat dilihat dan diketahui masyarakat secara transparan. Seluruh masyarakat Gampong Bireuen Meunasah Blang dan Meunasah Dayah dapat melihat realisasi pengalokasian dana desa pada baliho dan papan pengumuman yang dipublish oleh perangkat desa di lokasi yang strategis yaitu di depan masjid gampong masing-masing yang memang bersebelahan dengan kantor Geuchiknya.

Berdasarkan hasil wawancara dengan masyarakat Gampong Bireun Meunasah Blang dan Meunasah Dayah, bahwa selama ini masyarakat mengetahui alokasi ADD yang telah ditetapkan. Mengingat bahwa informasi telah dipublish secara umum. Salah satu masyarakat mengatakan bahwa transparansi ADD bisa dilihat melalui baliho tersebut. Namun, sebagian masyarakat kadang tidak menyadarinya atau tidak mau tahu informasi ADD tersebut. Namun masyarakat juga mengharapkan agar pemberian informasi kepada masyarakat perlu ditingkatkan, misalnya dengan memasang pengumuman tidak hanya pada satu tempat, mengingat luasnya daerah gampong tersebut.

\section{Kesimpulan dan Saran}

Pengelolaan dana gampong di kabupaten Bireun sudah berjalan secara transparan baik dari proses keterbukaan, proses perencanaan, penyusunan dan pelaksanaan Anggaran Dana Desa. Begitu halnya dengan kesediaan dan aksesibilitas dokumen, kejelasan dan kelengkapan informasi, keterbukaan proses dan kerangka regulasi yang menjamin transparansi.

\section{Daftar Pustaka}

Akhmad, I., Mustanir, A., \& Ramadhan, M. R. (2017). Pengaruh Pemanfaatan Tekhnologi Informasi Dan Pengawasan Keuangan Daerah Terhadap Kualitas Laporan Keuangan Kabupaten Enrekang. Sosial Politik \& Ekonomi.

Alfi, I. (2016). Proses Penyusunan Anggaran Pada Kementerian Pekerjaan Umum Direktorat Jenderal Sumber Daya Air Balai Wilayah Sungai Sumatera V (Doctoral dissertation, Universitas Andalas).

Anthony, R. N., Bedfrod, N. M., Dearden, J., \& Maulana, A. (1992). Sistem pengendalian manajemen. Binarupa Aksara.

Asyikin, A. N., Fitri, R., \& Nugroho, A. S. B. (2016). Masterplan Teknologi Informasi Dan Komunikasi (Tik) Kantor Pemerintah Desa. POROS TEKNIK, 8(2), 61-67.

Atmadja, A. T., Vijaya, D. P., \& Saputra, K. A. K. (2013). Akuntansi manajemen sektor publik. Singaraja: Universitas pendidikan Ganesha.

Bastian, I. (2007). Akuntansi yayasan dan lembaga publik. Jakarta: Erlangga.

Devi, A. Y. (2018). Peran Pejabat Pengelola Informasi Dan Dokumentasi (Ppid) Dalam Melaksanakan Keterbukaan Informasi Publik Di Kabupaten Indragiri Hulu (Doctoral dissertation, Universitas Islam Negeri Sultan Syarif Kasim Riau).

Diana, L. T. (2016). Pengaruh Partisipasi Anggaran Terhadap Kinerja Aparatur Pemerintah Daerah Kota Bandung (Studi Survey pada Satuan Kerja Perangkat Daerah Kota Bandung) (Doctoral dissertation, Universitas Widyatama). 
Gusmaulita, W. (2018). Pengaruh Partisipasi Penyusunan Anggaran Dan Komitmen Organisasi Terhadap Senjangan Anggaran Dengan Motivasi Dan Ketidakpastian Lingkungan Sebagai Variabel Moderating (Studi Empiris Pada Pemerintah Provinsi Riau) (Doctoral dissertation, Universitas Islam Negeri Sultan Syarif Kasim Riau).

Halim, A., an Muh, A. T., \& Husein, F. (2009). Sistem Pengendalian Manajemen (Edisi Revisi). Yogyakarta. UPP STIM YKPN.

Hari, S. (2016). Analisis Pengaruh Transparansi, Akuntabilitas, Dan Pemanfaatan Sistem Informasi Akuntansi Keuangan Daerah Terhadap Pengelolaan APBD (Studi Persepsi Pengelola APBD SKPD Pemerintah Kota Padang) (Doctoral dissertation, Universitas Andalas).

Hiban, R. I. (2018). Pengaruh Transparansi Dan Akuntabilitas Terhadap Kinerja Instansi Pemerintah Pada Instansi Pemerintah Kota Cimahi (Studi Survey Pada 20 SKPD Kota Cimahi) (Doctoral dissertation, Universitas Widyatama).

Hidayat, S. (2016). Pengaruh Implementasi Anggaran Berbasis Kinerja Dan Partisipasi Penyusunan Anggaran Terhadap Akurasi Estimasi Anggaran (Studi Kasus Pada Pemerintah Kabupaten Garut) (Doctoral dissertation, Tesis Program Magister Akuntansi Universitas Widyatama Bandung).

Holzner, B., \& Holzner, L. (2006). Transparency in global change: The vanguard of the open society. Pittsburgh.

Jubaedah, E., Lili, N., \& Faozan, H. (2008). Model Pengukuran Pelaksanaan Good Governance di Pemerintah Daerah Kabupaten/kota. Bandung: PKP2A I LAN.

Kaharti, E. (2019). Evaluasi Prosedur Penyusunan Anggaran dan Penetapan Anggaran. Jurnal Ilmiah Akuntansi dan Keuangan, 8(2), 1-6.
Kusuma, B. H. (2016). Pengaruh Partisipasi Penyusunan Anggaran Terhadap Kinerja Manajerial: Komitmen Organisasi Sebagai Variabel Mediasi. Jurnal Akuntansi Maranatha, 8(2), 203-213.

Laksono, F. (2017). Dimensi Manajerial dan Politik Proses Penyusunan dan Penetapan Anggaran Pendapatan dan Belanja Daerah (Studi Ketepatan Waktu Proses Penyusunan dan Penetapan Anggaran Pendapatan dan Belanja Daerah Kabupaten Blitar Tahun Anggaran 20132015). Jurnal Ilmiah Administrasi Publik, 3(1).

Mardiasmo, A. (2002). Otonomi dan Manajemen Keuangan Daerah: Good Governance, Democratization, Local Government Financial Management.

Mariastuti, S. D. (2019). Pengaruh Partisipasi Penyusunan Anggaran Terhadap Budgetary Slack Dengan Job Relevant Information Sebagai Variabel Moderating (Studi Kasus pada SKPD Kabupaten Sleman Tahun 2018) (Doctoral dissertation, Universitas Mercu Buana Yogyakarta).

Muhammad, F. (2016). Modernisasi Administrasi Publik Untuk Peningkatan Daya Saing. Antologi Administrasi Publik dan Pembangunan: Festschrift untuk Sjamsiar Sjamsuddin, 259.

Nurfitriani, A. (2018). Pengaruh Transparansi dan Akuntabilitas terhadap Pengelolaan Keuangan Desa (Studi pada Pemerintah Desa di Kabupaten Garut) (Doctoral dissertation, Universitas Widyatama).

Nurman. (2015). Strategi Pembagunan Daerah, Jakarta: Rajawali Pers.

Orinaldi, M., Tan, S., \& Putra, W. E. (2017). Pengaruh Partisipasi Anggaran Dan Motivasi Terhadap Kesenjangan Anggaran Dengan Good Governance Sebagai Variabel Pemoderasi Pada Kepala Skpd Provinsi Jambi. Jurnal Akuntansi \& Keuangan Unja, 2(3), 29-44. 
Pakaya, N., Rorong, A., \& Tulusan, F. (2019). Transparansi Pengolaan Badan Usaha Milik Desa (bumdes) di Desa Kamanga Kecamatan Tompaso. Jurnal Administrasi PUBLIK, 5(74).

Perdana, K. A., Sinarwati, N. K., Herawati, N. T., \& AK, S. (2017). "Perilaku Legislatif Badan Permusyawaratan Desa dalam Praktik Penganggaran Sektor Publik (APBDes) Desa Subuk". JIMAT (Jurnal Ilmiah Mahasiswa Akuntansi) Undiksha, $8(2)$.

Prayogi, R. (2019). Pengaruh Transparansi, Akuntabilitas, Dan Kepercayaan Kepada Pemerintah Desa Terhadap Partisipasi Masyarakat Dalam Pembangunan Desa (Doctoral dissertation, Universitas Islam Indonesia).

Rahman, M., \& Sucipto, N. (2018). Pengawasan terhadap Realisasi Anggaran dengan Konsep Good Governance dalam Mencegah Praktik Korupsi (Studi Kasus Dinas Pekerjaan Umum dan Penataan Ruang Kabupaten Gowa) (Doctoral dissertation, Universitas Islam Negeri Alauddin Makassar).

Salle, A. (2016). Makna transparansi dalam pengelolaan keuangan daerah. Keuda: Jurnal Kajian Ekonomi Dan Keuangan Daerah, 1(1).

Satriawan, E. S. B. (2016). Analisis Pengetahuan Dewan Perwakilan Rakyat Daerah Tentang Anggaran Terhadap Pengawasan Keuangan Daerah. JRAB: Jurnal Riset Akuntansi \& Bisnis, 9(2).

Sidauruk, J. (2017). Analisis Proses Penyusunan Anggaran Satuan Kerja Perangkat Daerah Pada Kantor Balai Besar Konservasi Sumber Daya Alam (BBKSDA) Medan.

SUTRISNO, N. (2017). Peranan Kepemimpinan Kepala Daerah Dalam Mengefektifkan Desentralisasi Fiskal Untuk Meningkatkan Pembangunan Dan Kesejahteraan Rakyat (Studi Kasus Pada
Penyelenggaraan Otonomi Daerah di Kabupaten Majalengka) (Doctoral dissertation, UNPAS).

TAHIR, E. (2018). Pengaruh Alokasi Dana Desa Terhadap Pemberdayaan dan Peningkatan Kesejahteraan Masyarakat. Skripsi. Fakultas Ekonomi dan Bisnis Universitas Halu Oleo, Kendari.

Tundunaung, L., Lumolos, J., \& Mantiri, M. (2018). Transparansi Pengelolaan Dana Desa Di Desa Tabang Kecamatan Rainis Kabupaten Kepulauan Talaud. Jurnal Eksekutif, 1(1).

Vabiani, D. P. (2018). Pengaruh Transparansi Dan Akuntabilitas Terhadap Kinerja Instansi Pemerintah (Survei pada Satuan Kerja Perangkat Daerah Kabupaten Bandung Barat) (Doctoral dissertation, Universitas Widyatama).

Wirjono, E. R., \& Raharjono, A. B. (2017). Pengaruh Karakteristik Personalitas Manajer terhadap Hubungan antara Partisipasi dalam Penyusunan Anggaran dengan Kinerja Manajerial. KINERJA, Volume 11, No.1, Th. 2007: Hal. 50-63.

Yuwono, S., \& Indrajaya, A. (2005). Penganggaran sektor publik. Bayumedia Pub.

Zaenudin, M. S. (2016). Pengaruh Kejelasan Sasaran Anggaran, Konflik Peran Dan Sistem Informasi Terhadap Efektivitas Sistem Pengendalian Manajemen (Studi pada PT. Kereta Api Indonesia Kota Bandung) (Doctoral dissertation, Fakultas Ekonomi dan Bisnis Unpas Bandung).

Zulfikar, M. (2017). Pengaruh Transparansi Dan Akuntabilitas Terhadap Kualitas Laporan Keuangan (Studi Kasus pada Dinas Penanaman Modal dan Pelayanan Terpadu Satu Pintu Kabupaten Subang) (Doctoral dissertation, Universitas Widyatama). 